\title{
Foliar Spray of Alpha-Tocopherol Modulates Antioxidant Potential of Okra Fruit under Salt Stress
}

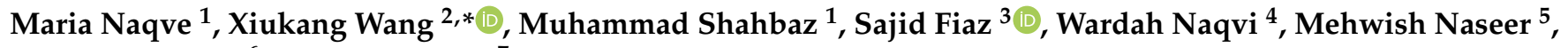 \\ Athar Mahmood ${ }^{6, *}$ and Habib Ali ${ }^{7}$
}

1 Department of Botany, Faculty of Sciences, University of Agriculture Faisalabad, Faisalabad 38000, Pakistan; marianaqvi26@gmail.com (M.N.); shahbazmuaf@yahoo.com (M.S.)

2 College of Life Sciences, Yan'an University, Yan'an 716000, China

3 Department of Plant Breeding and Genetics, The University of Haripur, Haripur 22620, Pakistan; sfiaz@uoh.edu.pk

4 Institute of Agricultural and Resource Economics, Faculty of Social Sciences, University of Agriculture Faisalabad, Faisalabad 38000, Pakistan; wardahnaqvi5@gmail.com

5 Department of Botany, Faculty of Science and Technology, Govt. College Women University Faisalabad, Faisalabad 38000, Pakistan; mehwishnaseer@gcwuf.edu.pk

6 Department of Agronomy, Faculty of Agriculture, University of Agriculture Faisalabad, Faisalabad 38000, Pakistan

7 Department of Agricultural Engineering, Khawaja Fareed University of Engineering and Information Technology, Rahim Yar Khan, Punjab 64200, Pakistan; habib_ali1417@yahoo.com

* Correspondence: wangxiukang@yau.edu.cn (X.W.); athar.mahmood@uaf.edu.pk (A.M.)

\section{check for} updates

Citation: Naqve, M.; Wang, X.; Shahbaz, M.; Fiaz, S.; Naqvi, W.; Naseer, M.; Mahmood, A.; Ali, H. Foliar Spray of Alpha-Tocopherol Modulates Antioxidant Potential of Okra Fruit under Salt Stress. Plants 2021, 10, 1382. https://doi.org/ $10.3390 /$ plants 10071382

\section{Academic Editors:}

Mirza Hasanuzzaman and

Masayuki Fujita

Received: 11 May 2021

Accepted: 29 June 2021

Published: 6 July 2021

Publisher's Note: MDPI stays neutral with regard to jurisdictional claims in published maps and institutional affiliations.

Copyright: (c) 2021 by the authors. Licensee MDPI, Basel, Switzerland. This article is an open access article distributed under the terms and conditions of the Creative Commons Attribution (CC BY) license (https:// creativecommons.org/licenses/by/ $4.0 /)$.

\begin{abstract}
As an antioxidant, alpha-tocopherol ( $\alpha$-Toc) protects plants from salinity-induced oxidative bursts. This study was conducted twice to determine the effect of $\alpha$-Toc as a foliar spray (at 0 (no spray), 100, 200, and $300 \mathrm{mg} \mathrm{L}^{-1}$ ) to improve the yield and biochemical constituents of fresh green capsules of okra (Abelmoschus esculentus L. Moench) under salt stress (0 and $100 \mathrm{mM})$. Salt stress significantly reduced $\mathrm{K}^{+}$and $\mathrm{Ca}^{2+}$ ion concentration and yield, whereas it increased $\mathrm{H}_{2} \mathrm{O}_{2}$, malondialdehyde (MDA), $\mathrm{Na}^{+}$, glycine betaine (GB), total free proline, total phenolics, and the activities of catalase (CAT), guaiacol peroxidase (GPX), and protease in both okra varieties (Noori and Sabzpari). Foliar application of $\alpha$-Toc significantly improved the yield in tested okra varieties by increasing the activity of antioxidants (CAT, GPX, SOD, and ascorbic acid), accumulation of GB, and total free proline in fruit tissues under saline and non-saline conditions. Moreover, $\alpha$-Toc application as a foliar spray alleviated the adverse effects of salt stress by reducing $\mathrm{Na}^{+}$concentration, MDA, and $\mathrm{H}_{2} \mathrm{O}_{2}$ levels and improving the uptake of $\mathrm{K}^{+}$and $\mathrm{Ca}^{2+}$. Among the tested okra varieties, Noori performed better than Sabzpari across all physio-biochemical attributes. Of all the foliar-applied $\alpha$-Toc levels, $200 \mathrm{mg} \mathrm{L}^{-1}$ and $300 \mathrm{mg} \mathrm{L}^{-1}$ were more effective in the amelioration of salinity-induced adverse effects in okra. Thus, we concluded that higher levels of $\alpha$-Toc $\left(200 \mathrm{mg} \mathrm{L}^{-1}\right.$ and $\left.300 \mathrm{mg} \mathrm{L}^{-1}\right)$ combat salinity stress more effectively by boosting the antioxidant potential of okra plants.
\end{abstract}

Keywords: antioxidants; alpha-tocopherol; foliar spray; salinity; okra varieties

\section{Introduction}

Okra [Abelmoschus esculentus (L.) Moench] is the most popular mallow crop and a common food crop in Asia. Its finger-like fruits, called capsules, are mainly consumed as a vegetable. These capsules are a rich source of vitamins, minerals and dietary fiber, and are low in calories. The mucilage's properties have medicinal enormous value [1]. The high mucilage content sets okra apart from other vegetables and makes it suitable for various medicinal and industrial applications [2].

A $90 \%$ loss $\left(6.5 \mathrm{dSm}^{-1}\right)$ in okra yield has been reported under high salt levels [3]. Soil salinity is one of the most prominent obstacles suppressing plant productivity. It remarkably affects the production of crops by disrupting the overall cellular metabolism of 
plants [4]. In Asia, it is expected that increasing levels of salinization could result in a loss of $50 \%$ of cultivated land by 2050 [5]. In developing countries like Pakistan, these losses are of considerable attention because its economy relies on agriculture. In Pakistan, 6 Mha of cultivated land is affected by salinity, which is a great threat to future food production [6].

Salinity affects plant growth and yield by reducing the photosynthesis rate, biomass, and water use efficiency [7]. The continued deposition of salts shunts osmotic stress, ionic imbalance, and physiological drought in plants [8]. The combination of these stresses directly influences fruit production in plants due to the considerable adverse effects on the composition of amino acids, proteins, and carbohydrates [9]. The production of reactive oxygen species (ROS) due to oxidation stress under high salt levels is another prominent threat as thesedamage the proteins, nucleic acids, and other biomolecules, thus limiting plant metabolism and yield [10]. This oxidative burst in the form of ROS induces the peroxidation of lipids, resulting in the production of lipid radicles and malondialdehyde (MDA), thereby damaging cellular membranes [11].

Plants have an antioxidant defense system to combat ROS. This system consists of enzymatic and non-enzymatic antioxidants found in all cellular compartments. These antioxidants detoxify cells from oxidative free radicles produced under varying saline regimes [12]. Oxidative damage generated under saline regimes can be alleviated by the exogenous application of these antioxidants [13]. Foliar spraying with $\alpha$-Toc is one such approach to the improvement of plant growth under salinity stress [14]. Tocopherols are members of the vitamin E family and consist of alpha, beta, gamma, and delta forms [14] $\alpha$-Toc is more active than all other categories of vitamin E, as it protects photosystem II and lipid membranes in chloroplasts from salinity-induced damages [13,14].

Tocopherols are non-enzymatic antioxidants which protect plants by quenching ROS and guard cellular membranes against lipid peroxidation [15]. Among these tocopherols, $\alpha$-Toc is the most active antioxidant as it shields photosystems from photo-inhibition and protects membrane lipids in chloroplasts under salinity stress [9]. As chloroplasts are sensitive to salinity stress [16], to combat salinity-induced ROS, $\alpha$-Toc works in coordination with other antioxidants, including catalase (CAT), superoxide dismutase (SOD), and guaiacol peroxidase (GPX) [17]. SOD is the first line of defense under stress conditions as it converts singlet oxygen species to $\mathrm{H}_{2} \mathrm{O}_{2}$, and this $\mathrm{H}_{2} \mathrm{O}_{2}$ is converted to $\mathrm{H}_{2} \mathrm{O}$ by CAT and GPX [18].

Few studies have assessed the impact of foliar spraying with $\alpha$-Toc in boosting the antioxidant potential of okra fruit under salt stress. Therefore, this study aimed to examine the modulations in antioxidant defense mechanism in response to $\alpha$-Toc foliar spray on the yield and the related attributes of okra under salt stress conditions.

\section{Results}

The data revealed that catalase (CAT) activity was significantly increased under salinity stress. Neither of the tested varieties of okra differ significantly in terms of CAT activity. Foliar spraying ( $300 \mathrm{mg} \mathrm{L}^{-1}$ ) with $\alpha$-Toc enhanced CAT activity in okra capsules under saline and non-saline conditions (Table 1; Figure 1A). 
Table 1. Analysis of variance (mean squares) for enzymatic and non-enzymatic antioxidants traits of okra treated with $\alpha$-Toc as foliar spray under saline and non-saline conditions.

\begin{tabular}{|c|c|c|c|c|c|c|c|c|}
\hline Source & df & CAT & POD & SOD & GPX & Protease & Phenolics & $\begin{array}{c}\text { Ascorbic } \\
\text { Acid }\end{array}$ \\
\hline $\mathrm{V}$ & 1 & $264.06 \mathrm{~ns}$ & $0.266 \mathrm{~ns}$ & $119.52 * *$ & $690,058.34^{* * *}$ & $28,532.84^{* * *}$ & $1.22 * * *$ & 1388.89 ns \\
\hline S & 1 & $15,314.06^{* * *}$ & $0.548 \mathrm{~ns}$ & $54.83 \mathrm{~ns}$ & $306,132.59 * * *$ & $8883.06^{* * *}$ & $293,265,625 * * *$ & $41,769.14^{* * *}$ \\
\hline$\alpha$-toc & 3 & $2143.22 * *$ & $0.515 \mathrm{~ns}$ & $16.29 \mathrm{~ns}$ & $279,930.76^{* * *}$ & 607.43 ns & $1.32^{* * *}$ & 4013.78 * \\
\hline $\mathrm{V} \times \mathrm{S}$ & 1 & $1501.56 \mathrm{~ns}$ & $0.523 \mathrm{~ns}$ & $47.23 \mathrm{~ns}$ & $290,599 \cdot 16^{* * *}$ & 70.84 ns & $3.94^{* * *}$ & $28,110.11^{* * *}$ \\
\hline $\mathrm{V} \times \alpha$-toc & 3 & $489.06 \mathrm{~ns}$ & $0.065 \mathrm{~ns}$ & $21.94 \mathrm{~ns}$ & $18,401.16 \mathrm{~ns}$ & $48,183.32 * * *$ & $6,912,135.4 \mathrm{~ns}$ & $3462.61 *$ \\
\hline$S \times \alpha$-toc & 3 & $205.72 \mathrm{~ns}$ & $0.997^{* *}$ & $6.42 \mathrm{~ns}$ & 4860.57 ns & $18,282.91 * * *$ & $32,911,354 * *$ & $16,191 \cdot 37^{* * *}$ \\
\hline $\mathrm{V} \times \mathrm{S} \times \alpha$-toc & 3 & $801.56 \mathrm{~ns}$ & $0.109 \mathrm{~ns}$ & $24.20 \mathrm{~ns}$ & $57,395.68 *$ & $7053.95 * * *$ & $9,296,354.2 \mathrm{~ns}$ & $13,829.37^{* * *}$ \\
\hline Error & 48 & 403.64 & 0.184 & 15.23 & $18,769.04$ & 404.83 & $6,673,880.2$ & 1109.76 \\
\hline
\end{tabular}

$*{ }^{* *}$ and ${ }^{* * *}=$ significant at $0.05,0.01$ and 0.001 levels respectively, ns = non-significant, V: Varieties, S: Salinity, $\alpha$-Toc: Alpha-tocopherol,

CAT: Catalase, POD: Peroxidase, SOD: Superoxide dismutase, GPX: Guaiacol peroxidase.

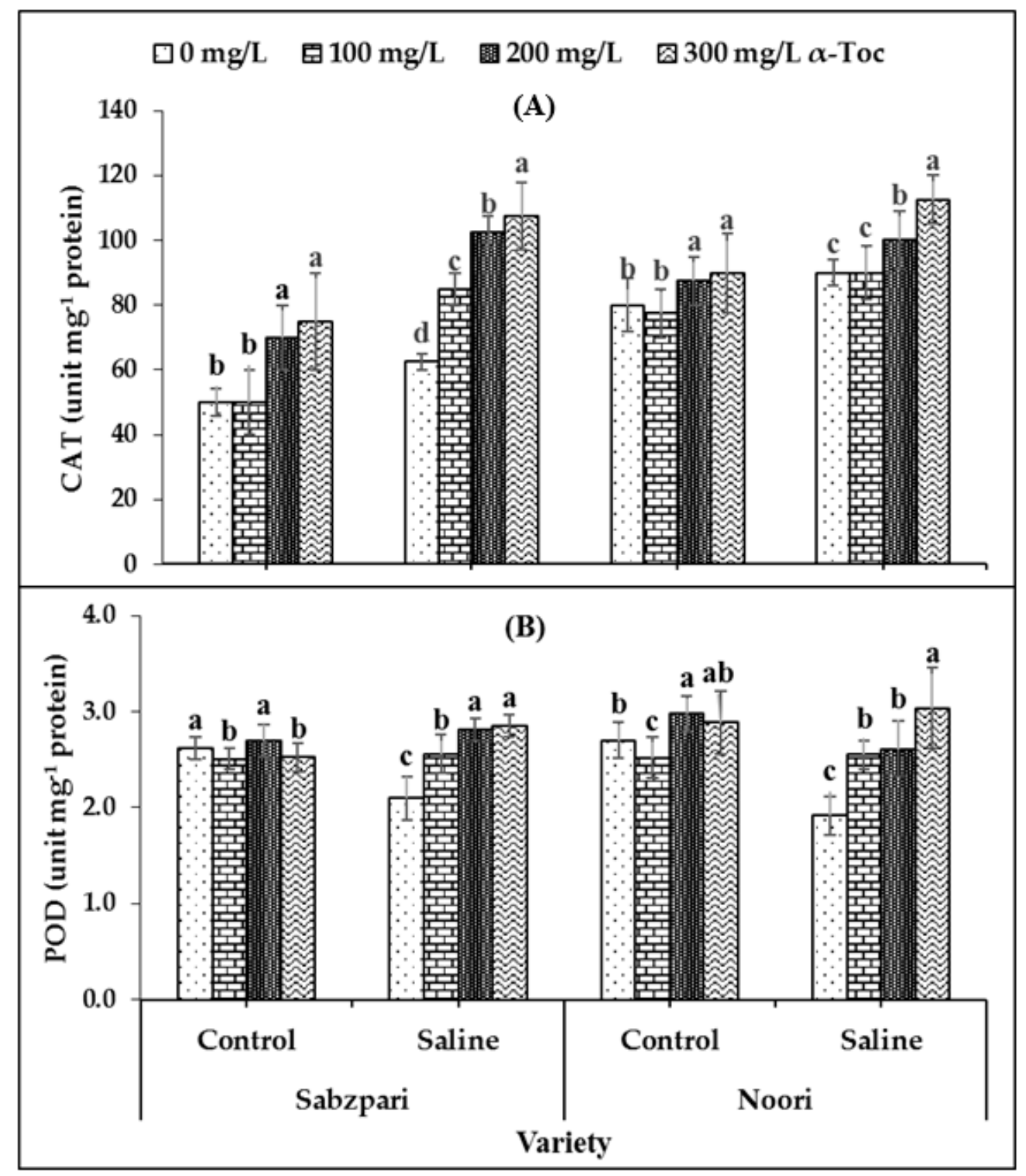

Figure 1. Effect of different levels of $\alpha$-Toc under saline and non-saline conditions on (A) activities of catalase (CAT) and (B) peroxidase (POD) of okra varieties sprayed with different levels of $\alpha$-Toc under saline and non-saline conditions. Values represent means \pm S.D. Significant differences among row spacing were measured by the least significant difference (LSD) at $p>0.05$ and indicated by different letters. S.D. stands for standard deviation. 
Both okra varieties demonstrated non-significant performance in term of peroxidase (POD) activity. Neither the application of salt stress nor $\alpha$-Toc affected the POD activity of the okra capsules. The data showed that root medium salinity had no effect on the activity of protease. However, a significant interaction was recorded between salinity and the $\alpha$-Toc spray, where $300 \mathrm{mg} \mathrm{L}^{-1}$ of the spray proved effective to increase the activity of POD under saline conditions (Table 1; Figure 1B).

The experimental data showed that root medium $100 \mathrm{mM}$ saline stress significantly enhanced the activity of guaiacol peroxidase (GPX) in the fruit tissues of both okra varieties. However, in the salinized Noori plants, GPX activity was slightly higher than Sabzpari. In addition, $\alpha$-Toc spray markedly improved the activity of GPX in both varieties. Inclusively, the $200 \mathrm{mg} \mathrm{L}^{-1}$ application of $\alpha$-Toc proved to be better at enhancing the activity of GPX (Table 1; Figure 2A).

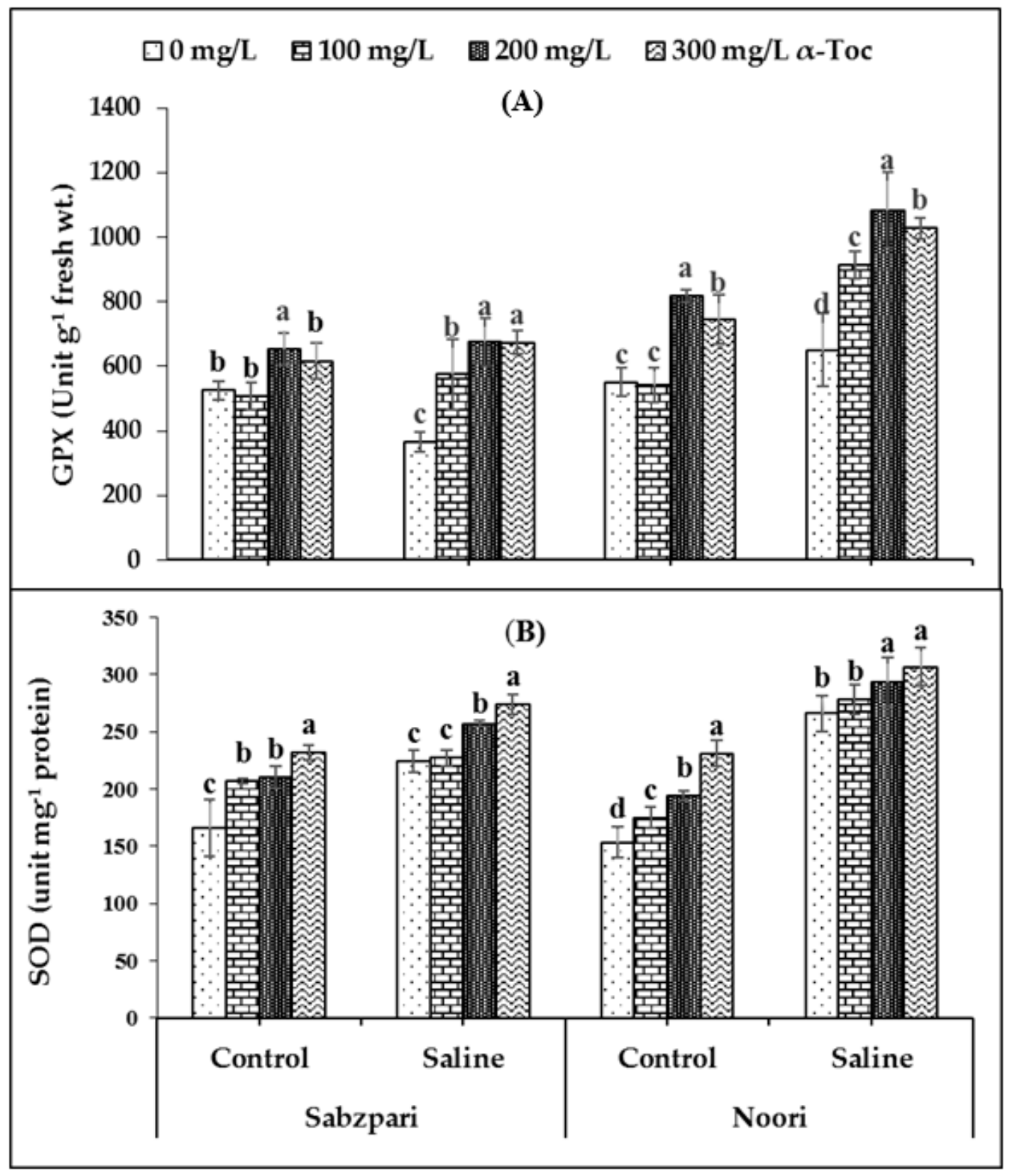

Figure 2. Effect of different levels of $\alpha$-Toc under saline and non-saline conditions on (A) activities of guaiacol peroxidase (GPX) and (B) superoxide dismutase (SOD) of okra varieties. Values represent means \pm S.D. Significant differences among row spacing were measured by the least significant difference (LSD) at $\mathrm{p}>0.05$ and indicated by different letters. S.D. stands for standard deviation. 
A slight increase in the activity of superoxide dismutase (SOD) in the fruits of both varieties of okra plants was noticed due to salinization. Interestingly, levels of superoxide dismutase (SOD) were higher in Noori than Sabzpari capsules under both stressed and non-stressed conditions. In the current study, foliar-applied $\alpha$-Toc failed to significantly affect the activity of SOD (Table 1; Figure 2B).

In this study, a significant decrease was recorded in the activity of protease under salinity stress. It was observed from the data that Noori performed better than Sabzpari with respect to this attribute. A significant interaction was also recorded among the tested varieties. The application of $200 \mathrm{mg} \mathrm{L}^{-1}$ spray of $\alpha$-Toc under saline conditions significantly enhanced the protease content of Noori okra in comparison with other treatments (Table 1; Figure 3A).

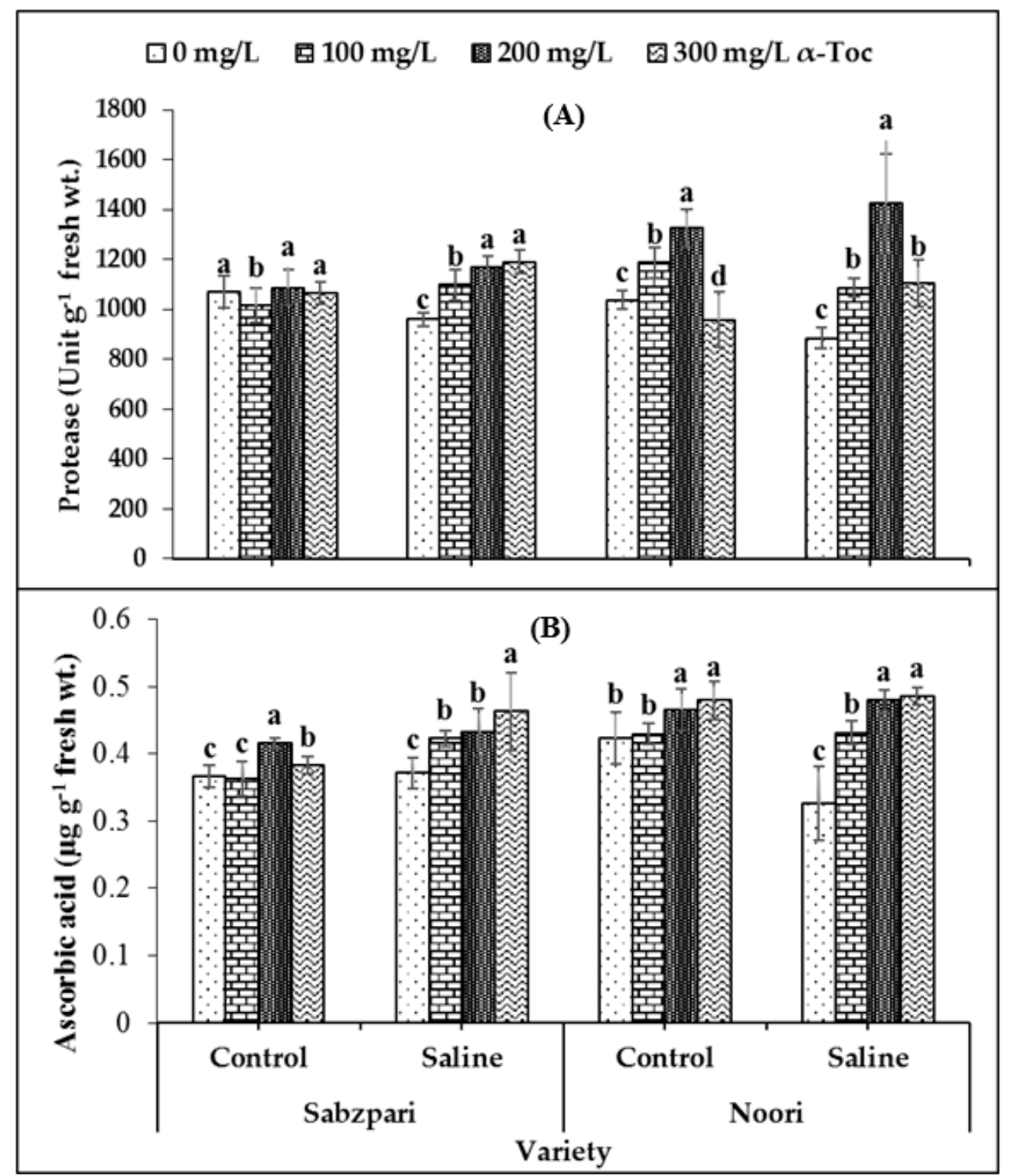

Figure 3. Effect of different levels of $\alpha$-Toc under saline and non-saline conditions on (A) activities of protease and (B) ascorbic acid of okra varieties. Values represent means \pm S.D. Significant differences among row spacing were measured by the least significant difference (LSD) at $p>0.05$ and indicated by different letters. S.D. stands for standard deviation.

A significant accumulation of ascorbic acid was recorded under salinity stress in the Noori variety, while it remained the same in Sabzpari under saline and control conditions. 
The application of $\alpha$-Toc significantly enhanced the ascorbic acid content in the Noori variety under saline conditions. Among all treatments, $\alpha$-Toc concentrations of $200 \mathrm{mg} \mathrm{L}^{-1}$ and $300 \mathrm{mg} \mathrm{L}^{-1}$ were more effective with respect to this attribute in the case of the Noori variety (Table 1; Figure 3B).

The data revealed that the total phenolics content significantly increased under salt stress. The tested varieties differed significantly in terms of total phenolics content. Noori produced more Sabzpari. Higher levels of applied $\alpha$-Toc $\left(200 \mathrm{mg} \mathrm{L}^{-1}\right.$ and $\left.300 \mathrm{mg} \mathrm{L}^{-1}\right)$ spray exhibited clearly higher total phenolics content under saline regimes (Table 1; Figure 4A).

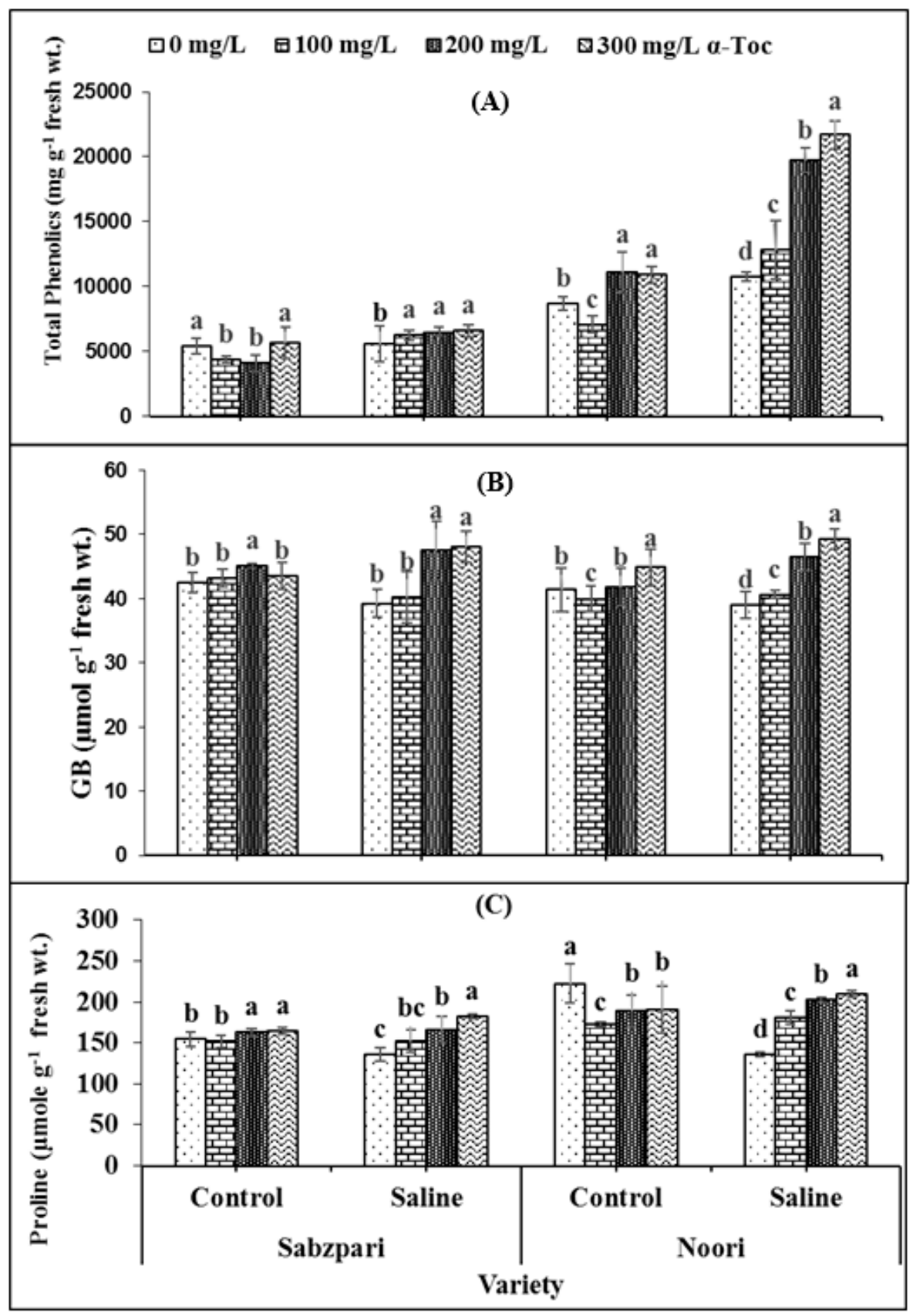

Figure 4. Effect of different levels of $\alpha$-Toc under saline and non-saline conditions on (A) total phenolics (B) glycinebetaine (GB), and (C) proline content of okra varieties. Values represent means \pm S.D. Significant differences among row spacing were measured by the least significant difference (LSD) at $p>0.05$ and indicated by different letters. S.D. stands for standard deviation. 
Both okra varieties have shown non-significant differences in terms of fruit glycine betaine (GB) and free proline contents. Root medium salinity stress non-significantly enhanced GB content (Table 2; Figure 4B,C) while markedly enhancing free proline in both okra varieties. Foliage supplementation with $\alpha$-Toc did not markedly affect the proline content of the fruit, whereas a significant interaction was observed between $\alpha$-Toc spray and salt stress with respect to the accumulation of proline content. Higher levels of $\alpha$-Toc spray produced significantly higher proline content under $100 \mathrm{mM}$ salt stress conditions as compared to other combinations. In addition, foliar spraying with $\alpha$-Toc at 200 and $300 \mathrm{mg} \mathrm{L}^{-1}$ significantly increased GB content in okra fruits of both varieties under controlled and stressed environments (Table 2; Figure 4B,C).

Table 2. Analysis of variance (mean squares) for osmolytes, ROS, ionic traits and yield of okra treated with $\alpha$-Toc as foliar spray under saline and non-saline conditions.

\begin{tabular}{|c|c|c|c|c|c|c|c|c|c|}
\hline Source & df & Proline & GB & $\mathrm{H}_{2} \mathrm{O}_{2}$ & MDA & $\mathrm{Na}^{+}$ & $\mathbf{K}^{+}$ & $\mathrm{Ca}^{2+}$ & $\mathrm{cap} / \mathrm{pl}$ \\
\hline $\mathrm{V}$ & 1 & $992.25 \mathrm{~ns}$ & $0.33 \mathrm{~ns}$ & $7284.92 *$ & $228.39 \mathrm{~ns}$ & $0.19 \mathrm{~ns}$ & $11.81 * * *$ & $8.6^{* *}$ & $43.89 * * *$ \\
\hline S & 1 & $10,905.3 * *$ & $316.19 \mathrm{~ns}$ & 3519.39 ns & $25,656.80 * * *$ & $53.47 * * *$ & $36.75 * * *$ & $30.9 * * *$ & $43.88^{* * *}$ \\
\hline$\alpha$-toc & 3 & $1983.47 \mathrm{~ns}$ & $1097.5 * *$ & $1344.55 \mathrm{~ns}$ & $5587.57 * *$ & $1.11 \mathrm{~ns}$ & $1.19 \mathrm{~ns}$ & $7.9^{* * *}$ & $9.515^{* *}$ \\
\hline $\mathrm{V} \times \mathrm{S}$ & 1 & $2102.87 \mathrm{~ns}$ & $5.3 \mathrm{~ns}$ & $63.87 \mathrm{~ns}$ & 8050.72 ** & $18.59 * * *$ & $1.72 \mathrm{~ns}$ & $3.7 *$ & $0.390 \mathrm{~ns}$ \\
\hline $\mathrm{V} \times \alpha$-toc & 3 & $2973.15 *$ & $313.3 *$ & $840.67 \mathrm{~ns}$ & $12,923.24 * * *$ & $6.34^{* * *}$ & $0.84 \mathrm{~ns}$ & $0.6 \mathrm{~ns}$ & $0.182 \mathrm{~ns}$ \\
\hline $\mathrm{S} \times \alpha$-toc & 3 & $3381.21 *$ & $548.0 * *$ & $1129.41 \mathrm{~ns}$ & $2793.45 \mathrm{~ns}$ & $0.79 \mathrm{~ns}$ & $3.51 * *$ & $2.2 *$ & $0.682 \mathrm{~ns}$ \\
\hline $\mathrm{V} \times \mathrm{S} \times \alpha$-toc & 3 & $9211.3^{* * *}$ & $9.3 \mathrm{~ns}$ & $404.06 \mathrm{~ns}$ & $3888.35 *$ & $0.96 \mathrm{~ns}$ & $0.60 \mathrm{~ns}$ & $0.2 \mathrm{~ns}$ & $0.182 \mathrm{~ns}$ \\
\hline Error & 48 & 1019.95 & 86.6 & 1014.53 & 1044.26 & 0.98 & 0.70 & 0.7 & 2.234 \\
\hline
\end{tabular}

${ }^{*}{ }^{* *}$ and ${ }^{* * *}=$ significant at $0.05,0.01$ and 0.001 levels respectively, ns = non-significant, V: Varie Table 2 . $\mathrm{O}_{2}, \mathrm{Hydrogen}$ peroxide, MDA: Malondialdehyde, cap/pl: Capsules per plant.

Interestingly, neither the foliar application of $\alpha$-Toc nor the application of salt $(\mathrm{NaCl})$ showed a clear impact on hydrogen peroxide $\left(\mathrm{H}_{2} \mathrm{O}_{2}\right)$ content. However, both okra varieties differed significantly in terms of hydrogen peroxide concentrations; Sabzpari accumulated more $\mathrm{H}_{2} \mathrm{O}_{2}$ than Noori under salt stress and non-stressed conditions (Table 2; Figure 5A).

Malondialdehyde (MDA) content was markedly enhanced under salt stress conditions in the Sabzpari variety. Foliar spraying with $\alpha$-Toc significantly reduced MDA contents under salinity treatment conditions. The experimental data of this study showed that higher levels of $\alpha$-Toc $\left(200 \mathrm{mg} \mathrm{L}^{-1}\right.$ and $300 \mathrm{mg} \mathrm{L}^{-1}$ ) were more effective at reducing the MDA content of okra (Table 2; Figure 5B).

Root medium applied salt stress was found to significantly enhance the fruit $\mathrm{Na}^{+}$ content of both okra varieties. The response of the two okra varieties was non-significant in terms of fruit $\mathrm{Na}^{+}$content. Foliar spraying with $\alpha$-Toc failed to have a significant impact on this ionic attribute, but the interactive effect of both varieties and $\alpha$-Toc was significant; it was found that 200 and $300 \mathrm{mg} \mathrm{L}^{-1}$ of foliar spray decreased $\mathrm{Na}^{+}$content in both varieties under saline and non-saline regimes. Noori performed better than Sabzpari in lowering the $\mathrm{Na}^{+}$ion content under salinity stress (Table 2; Figure 6A). 


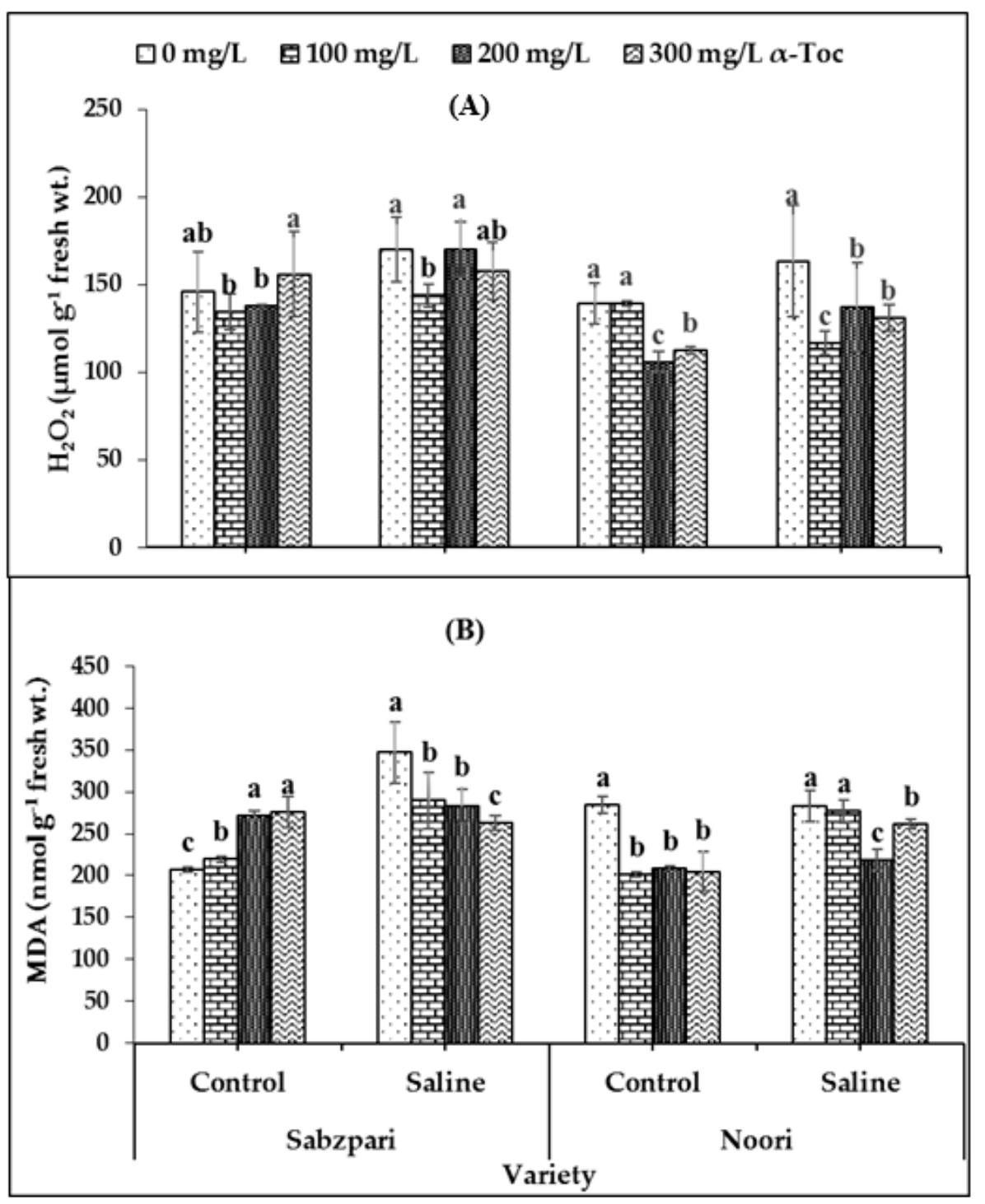

Figure 5. Effect of different levels of $\alpha$-Toc under saline and non-saline conditions on (A) hydrogen peroxide $\left(\mathrm{H}_{2} \mathrm{O}_{2}\right)$ and (B) malondialdehyde (MDA) content of okra varieties. Values represent means \pm S.D. Significant differences among row spacing were measured by the least significant difference (LSD) at $p>0.05$ and indicated by different letters. S.D. stands for standard deviation.

In this study, a clear reduction in fruit $\mathrm{K}^{+}$content was determined in both okra varieties under saline conditions. Although both varieties have shown significant differences in terms of fruit $\mathrm{K}^{+}$content, the Noori variety proved to be better at accumulating more $\mathrm{K}^{+}$ than Sabzpari under both salinity treatments. However, a significant interactive effect between $\alpha$-Toc and salinity stress was noted in this study. Higher levels of $\alpha$-Toc spray enhanced fruit $\mathrm{K}^{+}$content under salinity stress $(100 \mathrm{mM} \mathrm{NaCl})$ conditions in comparison with other combinations (Table 2; Figure 6B).

Repeated experimental data showed that soil salinization remarkably decreased fruit $\mathrm{Ca}^{2+}$ content in both okra varieties. Noori had higher fruit $\mathrm{Ca}^{2+}$ content than Sabzpari under the salinity-free regime. The interactive effect of both varieties towards salinity was also significant. Fruit $\mathrm{Ca}^{2+}$ content increased remarkably after foliar application of $\alpha$-Toc. The response of $\alpha$-Toc under salinity stress was also significant. Inclusively, $300 \mathrm{mg} \mathrm{L}^{-1}$ increased the fruit $\mathrm{Ca}^{2+}$ content in tested varieties under saline and no-saline environments (Table 2; Figure 6C). 


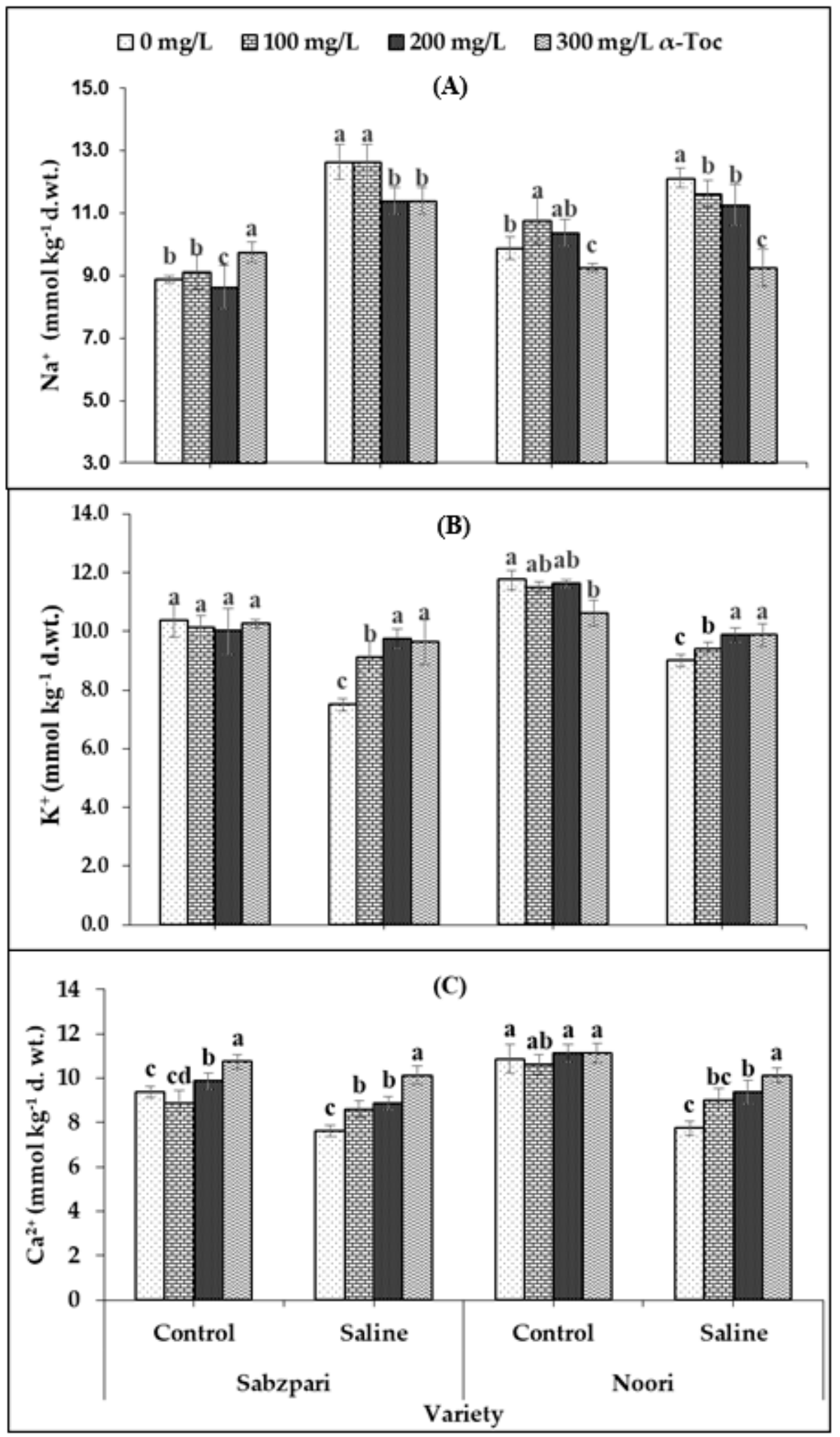

Figure 6. Effect of different levels of $\alpha$-Toc under saline and non-saline conditions on (A) $\mathrm{Na}^{+}(\mathbf{B}) \mathrm{K}^{+}$ and $(C) \mathrm{Ca}^{2+}$ ion content of okra varieties. Values represent means \pm S.D. Significant differences among row spacing were measured by the least significant difference (LSD) at $p>0.05$ and indicated by different letters. S.D. stands for standard deviation.

Salt stress significantly reduced the yield of both okra varieties in terms of the number of capsules plant ${ }^{-1}$. Both varieties differed markedly though; yield reduction was more 
pronounced in Sabzpari than Noori. However, foliar application of $\alpha$-Toc significantly enhanced the number of capsules in both okra varieties of stressed and non-stressed plants. In addition to this, enhancement in yield was more pronounced at $200 \mathrm{mg} \mathrm{L}^{-1}$ and $300 \mathrm{mg} \mathrm{L}^{-1}$ levels of $\alpha$-Toc application (Table 2; Figure 7).

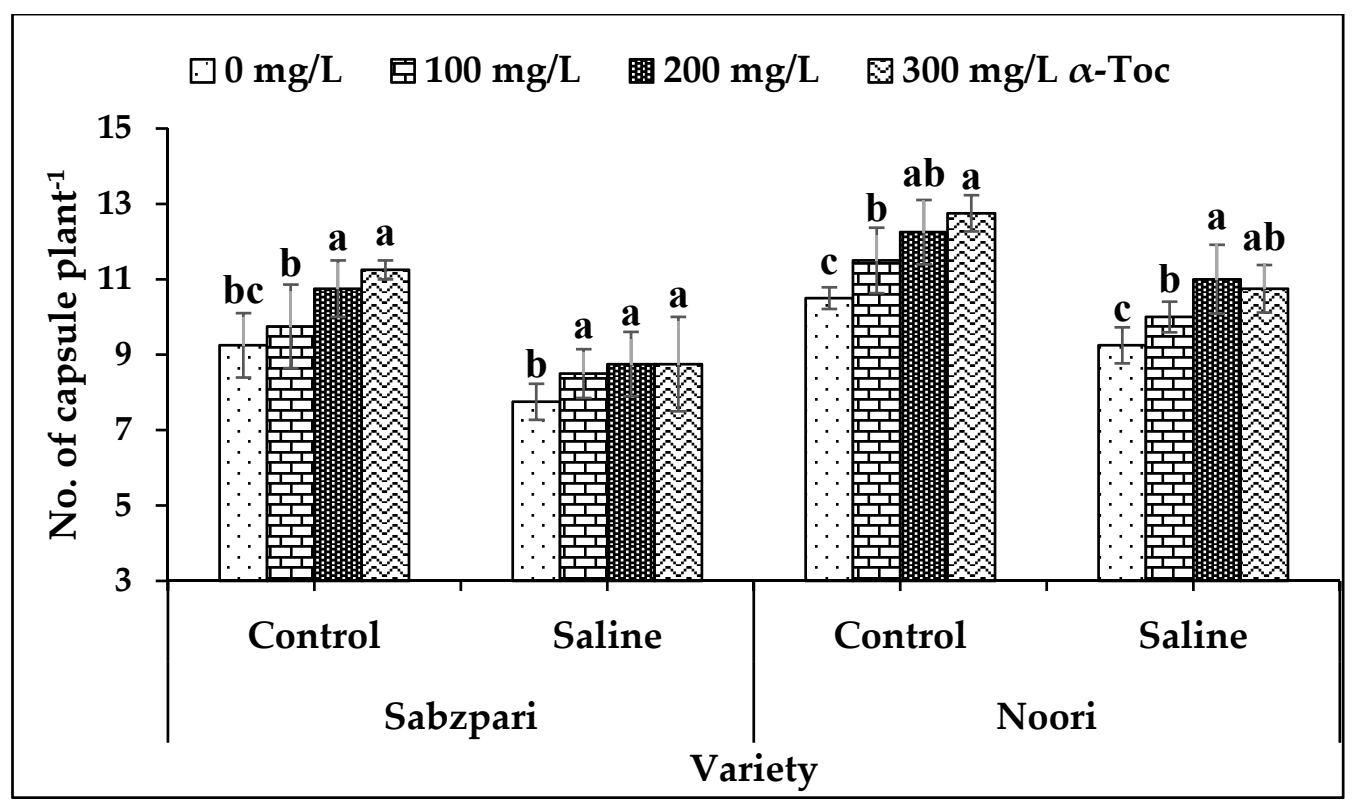

Figure 7. Effect of different levels of $\alpha$-Toc under saline and non-saline conditions on number of capsule Plant ${ }^{-1}$ of okra varieties. Values represent means \pm S.D. Significant differences among row spacing were measured by the least significant difference (LSD) at $p>0.05$ and indicated by different letters. S.D. stands for standard deviation.

\section{Discussion}

Salinity is considered an abiotic stress due to its potential to harm various physiological and biochemical processes in plants $[19,20]$. It influences plant performance, limiting its production and causing water shortages to the plants. Salinity also negatively affects chlorophyll, the photosynthetic apparatus, and chloroplast ultra-structure, and may cause cell death [21,22]. Salinity-induced ROS triggers phytotoxic reactions and adversely affects the cellular processes of plants, causing tissue damage due to the oxidization of macromolecules such as proteins and lipids. The induction of antioxidants is the prominent activity plants use to combat salinity-induced ROS stress [16]. Antioxidant enzymes are recognized as effective mitigators of the adverse effects of salt stress on cells and tissues [9]. The results of this study suggest that the activities of antioxidants, including CAT, GPX, and protease, were significantly increased due to salt stress in both varieties of okra plants. A slight but non-significant increase was observed in POD activity due to salt stress. The GPX is considered to be a defensive agent against oxidation induced by $\mathrm{H}_{2} \mathrm{O}_{2}$ [23], while POD is as efficient as GPX at scavenging $\mathrm{H}_{2} \mathrm{O}_{2}$ under salt stress conditions [24]. Previous research has shown that catalase plays an important role in ROS detoxification, converting 26 million $\mathrm{H}_{2} \mathrm{O}_{2}$ to $\mathrm{H}_{2} \mathrm{O}$ in one minute [25].

In the current study, the activities of these enzymes viz. CAT, POD, GPX, and protease were enhanced by the foliar fertigation of $\alpha$-Toc in fruit tissues of the tested okra varieties. To combat the overproduction of ROS, $\alpha$-Toc aids in the coordination of CAT, POD and GPX [26]. SOD activity was also increased in tested varieties of okra plants grown in saline medium, but $\alpha$-Toc spray did not significantly increase its activity. The enzyme SOD is considered to be the first line of defense against ROS. In a previous study, the activities of SOD, POD, and CAT were increased in two mung bean varieties under stress conditions [27]. Similarly, a study of Brassica napus showed a remarkable enhancement in the activity of SOD and POD enzymes, while a decline was noticed in the activity of CAT under stress conditions [28]. It is concluded from the findings of the present study that 
salt-stress-induced ROS accumulation is scavenged by $\alpha$-Toc antioxidants as they prevent ROS production by chelating metal ions. Moreover, $\alpha$-Toc fertigation could compensate for salinity-induced damages by upregulating other enzymatic antioxidants and quenching ROS via its antioxidant properties. Researchers have concluded that the stress-induced ROS accumulation is dependent on antioxidants, including $\alpha$-Toc [29].

Foliar spraying with $\alpha$-Toc improved ascorbic acid and total phenolic content in the tested okra plants under salt stress. It is suggested that ascorbic acid protects the plants against salinity effects by acting as a free radical reductant and antioxidant, and salt tolerance may have also been manifested by the upregulation of ascorbic acid, as it induces Toc biosynthesis and total phenols provide membrane stability against salinity-induced ROS. There is a positive correlation between spraying with $\alpha$-Toc and the acceleration of the content of total phenolics [30].

Glycine betaine (GB) has a significant role in stabilizing the structure and activity of protein complexes and enzymes and also maintains the membrane against devastating impacts caused by salinity [31]. Proline is effective in maintaining the potential of the osmotic process in the cytoplasm and in maintaining proteins and ribosomes against the harmful effects of $\mathrm{Na}^{+}$ions. In the current study, salt stress did not significantly affect the proline and GB content in fruit tissues of okra varieties. Contrary to this, previous research has shown a remarkable increase in the accumulation of GB and proline under stress [31]. Foliar spraying with $\alpha$-Toc significantly enhanced the proline and GB content, indicating its role in shielding the plants from salinity effects by adjusting the osmotic balance.

The ROS can induce the peroxidation of lipids (in MDA), producing aldehydes, of which MDA is a major type. MDA consequently has a role as an indicator of membrane damage induced by ROS. Our findings showed that neither the foliar application of $\alpha$-Toc nor salt $(\mathrm{NaCl})$ significantly affected $\mathrm{H}_{2} \mathrm{O}_{2}$ content, whereas MDA contents were increased under salt stress conditions in both okra varieties. In the current study, foliar spraying with $\alpha$-Toc significantly reduced MDA content under salinity stress in the tested okra capsules. Contrary to the present study, lower levels of $\mathrm{H}_{2} \mathrm{O}_{2}$ had been observed in Vicia faba plants treated with $\alpha$-tocopherol during salinity stress [14]. This could be due to the variation in genetic traits among different plant species. However, $\alpha$-Toc helped stabilize lipid membranes by scavenging ROS [32].

In this study, higher concentrations of $\mathrm{Na}^{+}$ions had been observed in the fruit tissues of okra plants under saline regimes. Enhanced $\mathrm{Na}^{+}$concentration disturbed photosynthesis, plant metabolism, enzymatic activities, and ultimately reduced crop yield [33,34]. In contrast, reduced uptake of $\mathrm{K}^{+}$and $\mathrm{Ca}^{2+}$ had been observed in the fruit tissues of the tested okra plants under salt stress conditions. The reduced uptake of $\mathrm{Ca}^{2+}$ and $\mathrm{K}^{+}$is correlated with the enhanced concentration of $\mathrm{Na}^{+} . \alpha$-Toc spray proved to be successful in minimizing the toxic concentrations of $\mathrm{Na}^{+}$and maximizing the concentration of $\mathrm{K}^{+}$and $\mathrm{Ca}^{2+}$ ion contents in fruit tissues of okra plants, suggesting its pivotal role in osmo-tolerance by lowering $\mathrm{Na}^{+}$levels and enhancing the uptake of $\mathrm{K}^{+}$and $\mathrm{Ca}^{2+}$ ions in plants under salinity conditions.

Plants are the target of abiotic stresses, thus suffering severe yield losses [35]. In the current investigation, reduced numbers of capsules were observed in okra under salinity stress. A reduction in the yield of crop plants under salinity stress is directly linked with inhibited uptake of essential nutrients [36]. However, $\alpha$-Toc supplementation significantly improved yield under saline and non-saline conditions. Increased yield due to $\alpha$-Toc spray is linked with the improved uptake of beneficial ions, ionic homeostasis, chloroplast stability, and reduced oxidative damage.

\section{Material and Methods}

Two-year pot experiments were carried out to examine the possible role of $\alpha$-Toc in modulating the antioxidant potential of okra capsules under salinity stress. Experiments were conducted in plastic pots (diameter $26 \mathrm{~cm}$, depth $29 \mathrm{~cm}$ ) each containing $10 \mathrm{~kg}$ of well washed river sand. The number of plots was 64 for each experiment. The crop 
duration was six months from sowing to harvesting. Each experiment was Seeds of two okra varieties (Sabzpari and Noori) were collected from the Ayub Agricultural Research Institute, Faisalabad, Pakistan. Experiment was laid out under completely randomized design (CRD) with four replications. Hoagland's nutrient solution $(1 \mathrm{~L} / \mathrm{pot})$ was applied weekly after sowing. Five plants were maintained in each pot. Twenty-four days old plants were treated with two salt levels $(0$ and $100 \mathrm{mM} \mathrm{NaCl})$ in Hoagland's nutrient solution. Concentration of $\mathrm{NaCl}$ was maintained in aliquot parts of $50 \mathrm{mM}$ to prevent salt shock. In fact, in order to avoid osmotic shocks to plants, the salinity level was maintained in two phases. In the first phase (at start of salinity) $50 \mathrm{mM} \mathrm{NaCl}$ level was maintained, and after two days at this level, the required level of $100 \mathrm{mM}$ was maintained. Foliar spray of each concentration of $\alpha$-Toc $(0,100,200$ and $300 \mathrm{mg} / \mathrm{L})$ was applied to 36 days old plants. The $50 \mathrm{~mL}$ solution of each of $\alpha$-Toc levels was foliar sprayed to fully saturate the plants. Tween 20 at $0.1 \%$ was used to enhance the absorbance of solution as surfactant. All plants were allowed to grow until the complete formation of capsules. Fresh green capsules of okra plants were collected from each plant, weighed, and used for chemical analyses as described below.

\subsection{Estimation of Enzymatic Antioxidants}

Fresh green capsule material $(0.5 \mathrm{~g})$ was homogenized with $10 \mathrm{~mL}(50 \mathrm{mM})$ potassium phosphate buffer with $\mathrm{pH}$ 7.0, after centrifugation supernatant was used for the determination of enzymatic antioxidants; activity of CAT and POD was determined by following the protocol of Chance and Maehly [37]. The procedure of Giannopolitis and Ries [36] was followed for recording the activities of SOD.

Protocol ascribed by Carlberg and Mannervik [38] was followed for the determination of GPX activities. Protease activities were recorded by following Drapeau et al. [39].

\subsection{Estimation of Non-Enzymatic Antioxidants}

For the determination of total phenolics content from the fresh green tissue of capsules, the protocol of Ainsworth and Gillespie [40] was followed. Ascorbic acid content from the capsules tissues of okra was determined by following the protocol established Mukherjee and Choudhuri [41]. Similarly, using the protocol established by Grieve and Grattan [42], glycinebetaine content was estimated from fresh fruit tissue.

The protocol ascribed by Bates et al. [43] was followed to estimate the free proline from the fruit material.

\subsection{Determination of ROS}

The procedure ascribed by Alexieva et al. [44] was adopted for the determination of $\mathrm{H}_{2} \mathrm{O}_{2}$ level, and by following procedure of Heath and Packer [45] with slight modifications [46] malondialdehyde (MDA) content was estimated.

\subsection{Nutrients Analysis for $\mathrm{Na}^{+}, \mathrm{K}^{+}$and $\mathrm{Ca}^{2+}$}

The protocol proposed by Wolf [47] was followed to determine mineral elements by acid digestion.

\subsection{Yield}

The plucked fresh capsules were collected, and yield (number of capsules/plants) was recorded.

\subsection{Statistical Analysis}

By following Snedecor and Cochran [48], analysis of variance (ANOVA) of data for all the parameters with four replicates was calculated under three factor factorial and design of experiment was completely randomized (CRD). The least significance difference (LSD) values at $5 \%$ probability were worked out and are presented in each figure. 


\section{Conclusions}

The foliar fertigation of $\alpha$-Toc was effective in compensating harmful salinity-induced effects in okra by enhancing antioxidant activities (CAT, POD, SOD, GPX, protease, ascorbic acid, total phenolics) and organic osmolytes (GB, free proline), as well as by improving ionic homeostasis and yield, possibly by quenching salinity-induced ROS and protecting chloroplasts with its antioxidant potential. Among the tested okra varieties, Noori showed better tolerance against salinity. $\alpha$-Toc levels of 200 and $300 \mathrm{mg} \mathrm{L}^{-1}$ were more effective. Thus, this study suggests the Noori variety can be grown in salt-affected soils with $\alpha$-Toc foliar spray $\left(300 \mathrm{mg} \mathrm{L}^{-1}\right)$ to increase okra production. The brutal effects of salinity can be mitigated in okra as well as other crops by foliar spraying with $\alpha$-Toc.

Author Contributions: M.S. and M.N. (Maria Naqve) conceived the idea; S.F., W.N. and M.N. (Mehwish Naseer) collected the literature review; X.W. and A.M. provided technical expertise to strengthen the basic idea. M.N. (Maria Naqve), M.S., W.N. and A.M. helped in collection of data and its analysis; H.A., M.S., A.M. and S.F. proofread and provided intellectual guidance. All authors have read the first draft, helped in revision and approved the article. All authors have read and agreed to the published version of the manuscript.

Funding: The publication of the present work is supported by the Natural Science Basic Research Program of Shaanxi Province (grant no. 2018JQ5218) and the National Natural Science Foundation of China (51809224), Top Young Talents of Shaanxi Special Support Program.

Institutional Review Board Statement: Not applicable.

Informed Consent Statement: Not applicable.

Data Availability Statement: Not applicable.

Conflicts of Interest: The authors declare that they have no conflict of interest.

\section{References}

1. Temam, N.; Mohammed, W.; Aklilu, S.; Belayneh, A.H.; Gebremedhin, K.G.; Egziabher, Y.G. Variability Assessment of Okra (Abelmoschus esculentus (L.) Moench) Genotypes Based on Their Qualitative Traits. Int. J. Agron. 2021, 2021, 6678561. [CrossRef]

2. Haruna, S.; Aliyu, B.S.; Bala, A. Plant gum exudates (Karau) and mucilages, their biological sources, properties, uses and potential applications: A review. Bayero J. Pure Appl. Sci. 2016, 9, 159-165. [CrossRef]

3. Mushtaq, N.U.; Saleem, S.; Rasool, A.; Shah, W.H.; Hakeem, K.R.; Rehman, R.U. Salt Stress Threshold in Millets: Perspective on Cultivation on Marginal Lands for Biomass. Phyton 2020, 90, 51. [CrossRef]

4. Mushtaq, Z.; Faizan, S.; Gulzar, B. Salt stress, its impacts on plants and the strategies plants are employing against it: A review. J. Appl. Biol. Biotechnol. 2020, 8, 81-91.

5. Khan, A.; Khan, A.L.; Muneer, S.; Kim, Y.-H.; Al-Rawahi, A.; Al-Harrasi, A. Silicon and salinity: Crosstalk in crop-mediated stress tolerance mechanisms. Front. Plant Sci. 2019, 10, 1429. [CrossRef]

6. Naveed, M.; Sajid, H.; Mustafa, A.; Niamat, B.; Ahmad, Z.; Yaseen, M.; Kamran, M.; Rafique, M.; Ahmar, S.; Chen, J.-T. Alleviation of salinity-induced oxidative stress, improvement in growth, physiology and mineral nutrition of canola (Brassica napus L.) through calcium-fortified composted animal manure. Sustainability 2020, 12, 846.

7. Moles, T.M.; de Brito Francisco, R.; Mariotti, L.; Pompeiano, A.; Lupini, A.; Incrocci, L.; Carmassi, G.; Scartazza, A.; Pistelli, L.; Guglielminetti, L. Salinity in autumn-winter season and fruit quality of tomato landraces. Front. Plant Sci. 2019, 10, 1078. [CrossRef]

8. Maria, N.; Muhammad, S.; Abdul, W.; Waraich, E.A. Seed priming with alpha tocopherol improves morpho-physiological attributes of okra under saline conditions. Int. J. Agric. Biol. 2018, 20, 2647-2654.

9. Sadiq, M.; Akram, N.A.; Ashraf, M.; Al-Qurainy, F.; Ahmad, P. Alpha-tocopherol-induced regulation of growth and metabolism in plants under non-stress and stress conditions. J. Plant Growth Regul. 2019, 38, 1325-1340.

10. Soltabayeva, A.; Ongaltay, A.; Omondi, J.O.; Srivastava, S. Morphological, Physiological and Molecular Markers for Salt-Stressed Plants. Plants 2021, 10, 243. [CrossRef] [PubMed]

11. Demidchik, V. Mechanisms of oxidative stress in plants: From classical chemistry to cell biology. Environ. Exp. Bot. 2015, 109, 212-228. [CrossRef]

12. Kumar, S.; Li, G.; Yang, J.; Huang, X.; Ji, Q.; Zhou, K.; Khan, S.; Ke, W.; Hou, H. Investigation of an Antioxidative System for Salinity Tolerance in Oenanthe javanica. Antioxidants 2020, 9, 940. [CrossRef]

13. Surówka, E.; Potocka, I.; Dziurka, M.; Wróbel-Marek, J.; Kurczyńska, E.; Żur, I.; Maksymowicz, A.; Gajewska, E.; Miszalski, Z. Tocopherols mutual balance is a key player for maintaining Arabidopsis thaliana growth under salt stress. Plant Physiol. Biochem. 2020, 156, 369-383. [CrossRef] [PubMed] 
14. Semida, W.; Taha, R.; Abdelhamid, M.; Rady, M. Foliar-applied $\alpha$-tocopherol enhances salt-tolerance in Vicia faba L. plants grown under saline conditions. S. Afr. J. Bot. 2014, 95, 24-31. [CrossRef]

15. Fritsche, S.; Wang, X.; Jung, C. Recent advances in our understanding of tocopherol biosynthesis in plants: An overview of key genes, functions, and breeding of vitamin E improved crops. Antioxidants 2017, 6, 99. [CrossRef]

16. Bose, J.; Rodrigo-Moreno, A.; Shabala, S. ROS homeostasis in halophytes in the context of salinity stress tolerance. J. Exp. Bot. 2014, 65, 1241-1257. [CrossRef] [PubMed]

17. Laxa, M.; Liebthal, M.; Telman, W.; Chibani, K.; Dietz, K.-J. The role of the plant antioxidant system in drought tolerance. Antioxidants 2019, 8, 94. [CrossRef]

18. Luis, A.; Corpas, F.J.; López-Huertas, E.; Palma, J.M. Plant superoxide dismutases: Function under abiotic stress conditions. In Antioxidants and Antioxidant Enzymes in Higher Plants; Springer: Berlin/Heidelberg, Germany, 2018; pp. 1-26.

19. Dubey, R.S. Photosynthesis in plants under stressful conditions. In Handbook of Photosynthesis; CRC Press: Boca Raton, FL, USA, 2018; pp. 629-649.

20. Singh, D. Stress Physiology; New Age International (P) limited, Publishers: New Dehli, India, 2003.

21. Stefanov, M.; Biswal, A.; Misra, M.; Misra, A.; Apostolova, E. Responses of Photosynthetic Apparatus to Salt Stress: Structure, Function, and Protection. In Handbook of Plant and Crop Stress, 4th ed.; CRC Press: Boca Raton, FL, USA, 2019 ; pp. $233-250$.

22. Muhammad, I.; Shalmani, A.; Ali, M.; Yang, Q.-H.; Ahmad, H.; Li, F.B. Mechanisms regulating the dynamics of photosynthesis under abiotic stresses. Front. Plant Sci. 2021, 11, 2310. [CrossRef] [PubMed]

23. Wang, W.-B.; Kim, Y.-H.; Lee, H.-S.; Kim, K.-Y.; Deng, X.-P.; Kwak, S.-S. Analysis of antioxidant enzyme activity during germination of alfalfa under salt and drought stresses. Plant Physiol. Biochem. 2009, 47, 570-577. [CrossRef]

24. Rady, M.; Sadak, M.S.; El-Bassiouny, H.; El-Monem, A. Alleviation the adverse effects of salinity stress in sunflower cultivars using nicotinamide and $\alpha$-tocopherol. Aust. J. Basic Appl. Sci. 2011, 5, 342-355.

25. Mehla, N.; Sindhi, V.; Josula, D.; Bisht, P.; Wani, S.H. An introduction to antioxidants and their roles in plant stress tolerance. In Reactive Oxygen Species and Antioxidant Systems in Plants: Role and Regulation under Abiotic Stress; Springer: Berlin/Heidelberg, Germany, 2017; pp. 1-23.

26. Hasanuzzaman, M.; Nahar, K.; Fujita, M. Plant response to salt stress and role of exogenous protectants to mitigate salt-induced damages. In Ecophysiology and Responses of Plants under Salt Stress; Springer: Berlin/Heidelberg, Germany, 2013 ; pp. $25-87$.

27. Ali, Q.; Javed, M.T.; Noman, A.; Haider, M.Z.; Waseem, M.; Iqbal, N.; Waseem, M.; Shah, M.S.; Shahzad, F.; Perveen, R. Assessment of drought tolerance in mung bean cultivars/lines as depicted by the activities of germination enzymes, seedling's antioxidative potential and nutrient acquisition. Arch. Agron. Soil Sci. 2018, 64, 84-102. [CrossRef]

28. Abedi, T.; Pakniyat, H. Antioxidant enzymes changes in response to drought stress in ten cultivars of oilseed rape (Brassica napus L.). Czech J. Genet. Plant Breed. 2010, 46, 27-34. [CrossRef]

29. Szarka, A.; Tomasskovics, B.; Bánhegyi, G. The ascorbate-glutathione- $\alpha$-tocopherol triad in abiotic stress response. Int. J. Mol. Sci. 2012, 13, 4458. [CrossRef]

30. Li, J.; Jin, H. Regulation of brassinosteroid signaling. Trends Plant Sci. 2007, 12, 37-41. [CrossRef] [PubMed]

31. Sakamoto, A.; Murata, N. The role of glycine betaine in the protection of plants from stress: Clues from transgenic plants. Plant Cell Environ. 2002, 25, 163-171. [CrossRef]

32. Tavakkoli, E.; Rengasamy, P.; McDonald, G.K. High concentrations of $\mathrm{Na}^{+}$and $\mathrm{Cl}^{-}$ions in soil solution have simultaneous detrimental effects on growth of faba bean under salinity stress. J. Exp. Bot. 2010, 61, 4449-4459. [CrossRef]

33. Ashraf, M.; Harris, P.J. Photosynthesis under stressful environments: An overview. Photosynthetica 2013, 51, 163-190. [CrossRef]

34. Farooq, M.; Gogoi, N.; Barthakur, S.; Baroowa, B.; Bharadwaj, N.; Alghamdi, S.S.; Siddique, K. Drought stress in grain legumes during reproduction and grain filling. J. Agron. Crop. Sci. 2017, 203, 81-102. [CrossRef]

35. Wang, X.; Wang, G.; Guo, T.; Xing, Y.; Mo, F.; Wang, H.; Fan, J.; Zhang, F. Effects of plastic mulch and nitrogen fertilizer on the soil microbial community, enzymatic activity and yield performance in a dryland maize cropping system. Eur. J. Soil Sci. 2021, 72, 400-412. [CrossRef]

36. Wang, X.; Fan, J.; Xing, Y.; Xu, G.; Wang, H.; Deng, J.; Wang, Y.; Zhang, F.; Li, P.; Li, Z. The effects of mulch and nitrogen fertilizer on the soil environment of crop plants. Adv. Agron. 2019, 153, 121-173.

37. Chance, B.; Maehly, A. Assay of catalases and peroxidases. Methods Enzymol. 1955, 2, 764-775.

38. Giannopolitis, C.N.; Ries, S.K. Superoxide dismutases: I. Occurrence in higher plants. Plant Physiol. 1977, 59, 309-314. [CrossRef]

39. Carlberg, I.; Mannervik, B. Glutathione reductase. Methods Enzymol. 1985, 113, 484-490. [PubMed]

40. Drapeau, G. Protease from Staphylococcus Aureus, Method of Enzymology 45b, L; Academic Press: New York, NY, USA, 1974.

41. Ainsworth, E.A.; Gillespie, K.M. Estimation of total phenolic content and other oxidation substrates in plant tissues using Folin-Ciocalteu reagent. Nat. Protoc. 2007, 2, 875-877. [CrossRef] [PubMed]

42. Mukherjee, S.; Choudhuri, M. Implications of water stress-induced changes in the levels of endogenous ascorbic acid and hydrogen peroxide in Vigna seedlings. Physiol. Plant. 1983, 58, 166-170. [CrossRef]

43. Grieve, C.; Grattan, S. Rapid assay for determination of water soluble quaternary ammonium compounds. Plant Soil 1983, 70, 303-307. [CrossRef]

44. Bates, L.S.; Waldren, R.P.; Teare, I. Rapid determination of free proline for water-stress studies. Plant Soil 1973, $39,205-207$. [CrossRef] 
45. Alexieva, V.; Sergiev, I.; Mapelli, S.; Karanov, E. The effect of drought and ultraviolet radiation on growth and stress markers in pea and wheat. Plant Cell Environ. 2001, 24, 1337-1344. [CrossRef]

46. Dhindsa, R.S.; Plumb-Dhindsa, P.; Thorpe, T.A. Leaf senescence: Correlated with increased levels of membrane permeability and lipid peroxidation, and decreased levels of superoxide dismutase and catalase. J. Exp. Bot. 1981, 32, 93-101. [CrossRef]

47. Wolf, B. A comprehensive system of leaf analyses and its use for diagnosing crop nutrient status. Commun. Soil Sci. Plant Anal. 1982, 13, 1035-1059. [CrossRef]

48. Snedecor, G.W.; Cochran, W.G. Statistical Methods, 7th ed.; Iowa State University Press: Ames, IA, USA, 1980. 